\title{
SERUM CHOLINESTERASE ACTIVITY FOLLOWING ENFLURANE ANAESTHESIA
}

\author{
P. Kaniaris, A. Fassoulaki, and K. Liarmakopoulou
}

\begin{abstract}
SERUM CHOLINESTERASE activity is inhibited by several drugs such as anticancer agents, ${ }^{1}$ ecothiopate-iodide eye drops, ${ }^{2}$ muscle relaxants, ${ }^{3}$ and anaesthetics such as ketamine..$^{4}$ Of the volatile anaesthetics it has been suggested that methoxyfluorane may result in decrease of cholinesterase activity. ${ }^{5}$ Since enflurane was introduced to anaesthetic practice there has been no report of its effect on serum cholinesterase activity. Therefore we have undertaken the present study to investigate the cholinesterase levels in healthy women after administration of enflurane anaesthesia.
\end{abstract}

\section{Materials and Methods}

\section{Patients}

Thirty adult female patient setween 25 and 38 years of age and with no evidence of renal or hepatic disease were studied. All of them presented for removal of lumps in the breast and after microscopic examination of frozen sections appeared to be negative for cancer. Premedication was atropine $0.6 \mathrm{mg}$ given intramuscularly one hour before induction of anaesthesia. Induction of anaesthesia was inhalational through a Mapleson A circuit. Surgical anaesthesia was maintained with oxygen-nitrous oxide $3 / 6$ litres$\mathrm{min}^{-1}$ and enflurane 1.5 to 3 per cent. Enflurane was delivered from an enfluratec vapourizer. No intravenous fluids were given during the period of anaesthesia to avoid dilutional effects on cholinesterase concentration. The duration of anaesthesia was 60 to 70 minutes while the surgical procedure lasted between 50 and 60 minutes.

Venous blood samples for serum cholinesterase determinations were taken before induction of anaesthesia, as soon as the operation was finished and 24 hours post-operatively. The sam.

P. Kaniaris, M.D., M.Sc., D.A., Acting Head of Anaesthesiology. Associate in Pharmacology. A. Fassoulaki, M.D., M.Sc., and K. Liarmakopoulou, M.D., Research Assistants, Department of Experimental Pharmacology, Department of Experimental Pharmacology, Division of Anaesthesiology, Medical School, University of Athens.

Correspondence to: P. Kaniaris, M.D., 43 Meandroupoleos Str., Athens 605, Greece. ples were centrifuged at $3000 \mathrm{jpm}$, serum was kept at $4^{\circ} \mathrm{C}$, and enzyme activity was determined within the next two hours.

\section{Assay method}

Serum cholinesterase activity was determined by the Boerhinger cholinesterase kit, which is based on a colormetric assay technique (normal values $3000-9300 \mathrm{U} / \mathrm{L}){ }^{6}$ Butyrylthiocholine is used as the substrate and the thiocholine produced by enzymatic hydrolysis reacts with 5,5 dithiobisnitrobenzoate to form 2-nitro-5-mercaptobenzoate which is estimated photometrically at wave length $405 \mathrm{~nm}$ (Coleman Junior II Photometer, cuvette $1 \mathrm{~cm}$ light path). The statistical analysis of the results was done by the Student's t test for paired data.

\section{RESULTS}

Table I and Figure I show the mean values $(\bar{X})$ of serum cholinesterase activity and the standard error (SE) for the $\mathbf{3 0}$ individuals before enflurane anaesthesia, at the end of the operation and 24 hours thereafter. Though the mean serum cholinesterase activity is decreased by more than 1000 U/L after 50 to 60 minutes of enflurane anaesthesia (a statistically significant difference, $\mathrm{P}<$ 0.01), still the enzyme levels remain within the normal limits. The mean chol inesterase values 24 hours postoperatively are restored nearly to the preoperative levels.

\section{Discussion}

One of the metabolic products of enflurane is inorganic fluoride ion, which can inhibit serum cholinesterase. Harris and Whittaker have shown that a fluoride concentration of $50 \mu \mathrm{m}$ will produce about 60 per cent inhibition of serum cholinesterase in viro.?

Braswell and Kitz studied in vitro the effect of several volatile anaesthetics on the enzymatic activity of human serum cholinesterase. ${ }^{8}$ The enzyme was found to be insensitive to saturated solutions of all the anaesthetics studied (halothane, ether, isoflurane, enflurane, methoxyflurane). However, the effect of volatile 
TABLE I

Mean Serum CHE Values ( $\bar{X}$ ) and Standard Error (SE) Before Enflurane Anaesthesia, at the End of the Operation and 24 Hours Post-operatively

\begin{tabular}{cccc}
\hline & Before anaesthesia & End of operation & $\begin{array}{c}24 \text { hours } \\
\text { post-operatively }\end{array}$ \\
\hline $\begin{array}{ccc}\text { Mean } \\
(\bar{X})\end{array}$ & $5668.41 \stackrel{P<0,01}{\longleftrightarrow}$ & $4618.03 \stackrel{P<0,05}{\rightleftarrows}$ & 5416.93 \\
SEM & 234.56 & 280.31 & 238.20
\end{tabular}

CHE: cholinesterase.

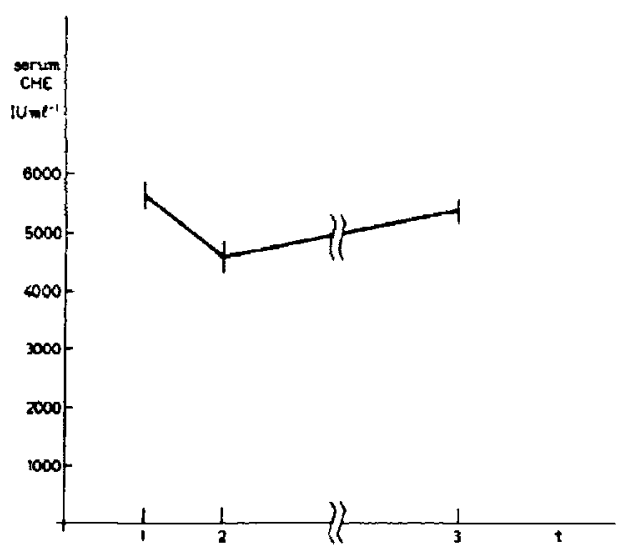

FIGURE I Serum cholinesterase: I, before enfiurane anaesthesia; 2 , at the end of enflurane anaesthesia; 3,24 hours post-operatively.

anaesthetics on the activity of serum cholinesterase in vitro may be unrelated to anaesthetic potency in vivo.

Apparently little work if any is available with reference to serum cholinesterase activity and volatile anaesthetics. Our data demonstrate a temporary decrease for serum cholinesterase activity after enflurane anaesthesia which can not be considered clinically significant (the enzyme levels still remain within normal limits). The exact mechanism of this decrease is unclear and can not be attributed to fluoride liberation, as methoxyfluorane does not depress cholinesterase concentration," although fluoride production is much greater.

On the other hand nitrous oxide, as an inert gas, is not expected to affect serum cholinesterase values and this is confirmed by studies during nitrous oxide-oxygen anaesthesia (control group) where enzyme activity is not significantly changed. ${ }^{5.9}$

This reversible inhibition of serum cholinesterase by enflurane could, however, enhance already depressed enzyme levels in patients with carcinomatosis, liver disease, receivers of various cholinesterase inhibitors (drugs), or in women in the second half of pregnancy, labour and early postpartum days. Besides in cases where anaesthesia is maintained by enflurane and intermittent doses of suxamethonium or in enflurane-propanidid combined anaesthesia ${ }^{10}$ the temporary serum cholinesterase inhibition may be of importance.

In conclusion, in normal patients serum cholinesterase activity remains at sufficiently high levels during the awakening stage after enflurane anaesthesia and is restored nearly to the pre-operative levels 24 hours post-operatively.

\section{SUMMARY}

Serum cholinesterase activity was determined in 30 fernale patients anaesthetized with enfurane for excision of lump in the breast. In all $30 \mathrm{pa}-$ tients biopsy of the tumor was negative for carcinoma. Blood samples were taken before induction of anaesthesia, at the end of the operation and 24 hours after the operation. Enzymatic determinations were performed by the Boerhinger cholinesterase kit.

Enzyme levels were found sufficiently high at the end of the operation and returned to the preoperative levels 24 hours post-operatively.

\section{RÉSUMÉ}

L'activité de la cholinestérase sérique a été étudiée chez trente malades du sexe féminin subissant l'exérèse d'une masse au sein. Aucune des lésions ne s'est avérée maligne. Des échantillons de sang furent prélevés avant l'induction de l'anesthésie, à la fin de l'opération et 24 heures plus tard. Les dosages enzymatiques ont été effectués par la technique Boerhinger.

Tout en demeurant dans les limites normales, l'activité cholinestérasique a subis une baisse significative à la fin de l'opération. Le retour au 
niveau pré-opératoire s'est produit dans les 24 heures.

\section{REFERENCES}

1. WANG, R.H. \& Ross, C.A. Prolonged apnoea following succinylcholine in cancer patients receiving AB-132. Anesthesiology $24: 363$ (1963)

2. MCGavi, D.D.M. Depressed levels of serum pseudocholinesterase with ecothiopate-iodide eyedrops. Lancet $2: 272(1965)$.

3. Stovner, J., Ofteda1, N., \& Houmboe, J. The inhibition of cholinesterase by pancuronium. Brit. J. Anaesth. 47: 949 (1975),

4. Sснин, T.F. Influence of ketamine on human plasma cholinesterase. Brit. J. Anaesth. 47: 1315 (1975).

5. Palahniuk, R.J. \& Cumming, R.N. Selum cholinesterase activity following the use of methoxyflurane in obstetrics. Anesthesiology 47: $\$ 20$ (1977).
6. KNEDEL, M. \& BötTGER, R. Eine kinetische method zur bestimmung der aktivität der pseudocholinesterase. Klin. Wschr. 45: 325 (1967).

7. HaRRIS, H. \& WhitrakeR, M. Differential inhibition of human serum cholinesterase with fluoride: Recognition of two new pheno-types. Nature 191: 496 (1961).

8. Braswell, L.M. \& Kitz, R.J. The effect in virro of volatile anesthetics on the activity of cholinesterases J. Neurochem. 29: 665 (1977).

9. Stoelting, R.K. Serum cholinesterase activity following pancuronium and antagonism with neostigmine or pyridostigmine. Anesthesiology. 45: 674 (1976).

10. Manani, G. Fierro, G. Zoccali, G. Comelli, L., \& Gasparerto, A. Ethrane and continuous intravenous propanidid for clinical anesthesia. Acta Anesthe siologica Italica 25: 1 (1974). (Ahbott Abstracts). 